ppi $201502 Z U 4645$

Esta publicación cientifica en formato digital es continuidad de la revista impresa ISSN-Versión Impresa 0798-1406 / ISSN-Versión on line 2542-3185Depósito legal pp

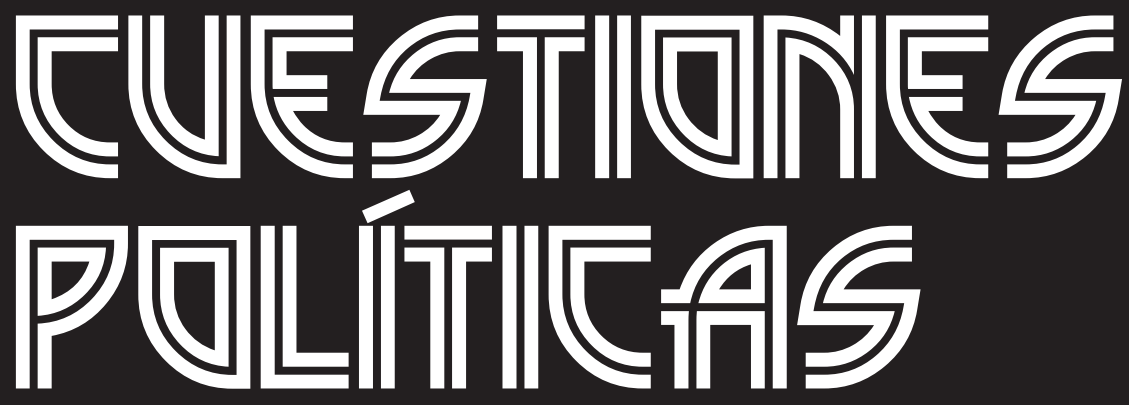

Instituto de Estudios Políticos y Derecho Público "Dr. Humberto J. La Roche' de la Facultad de Ciencias Jurídicas y Políticas de la Universidad del Zulia Maracaibo, Venezuela
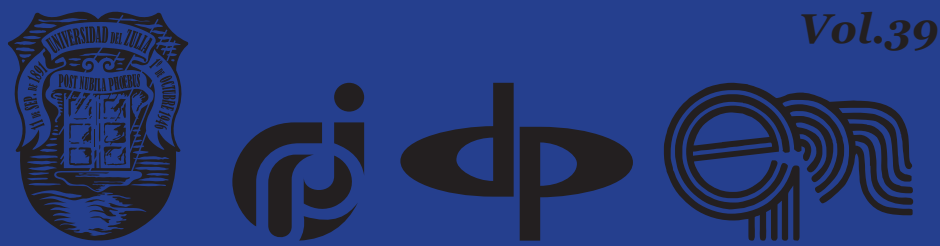


\title{
Legal linguistics as a promising field of knowledge
}

\author{
DOI: https://doi.org/10.46398/cuestpol.3968.36
}

\author{
Petro V. Makushev * \\ Olha $V$. Minchenko ** \\ Iryna V. Tsareva $^{* * *}$
}

\begin{abstract}
The relevance of the article is stipulated for the necessity to study a new and promising field of knowledge - legal linguistics. The purpose of the article is to study legal linguistics as a promising field of knowledge. Achieving the goal of the study necessitated processing the scientific literature on legal techniques, hermeneutics, linguistic interpretation, public speaking, and legal linguistics. The main method while studying these issues is the hermeneutic method, which is programmed for a new approach to understanding and interpreting the language of law and the language of laws, legal language formation and allowed to understand the text as a process of interpretation. The problems of linguistic field, interaction of linguistics and law are revealed, the specific functioning of language in the field of law is analyzed. Prospects of combining legal and linguistic competence, interpretation of texts of laws, speeches of judges and lawyers, and legal translation are studied. The article emphasizes the necessity to single out such a field of knowledge as legal linguistics and the
\end{abstract} prospects for its development are outlined.

Keywords: language of law; legal technique; legal field; jurisprudence; legal linguistics.

* Department of General and Law Subjects, Dnipovskii University of the Humanities, Ukraine. ORCID ID: https://orcid.org/oooo-0oo1-8693-1428. Email: makushev5514-2-10@uohk.com.cn

** Department of Theory of State and Law, National Academy of Internal Affairs, Ukraine. ORCID ID: https://orcid.org/oooo-ooo1-7746-0919. Email: minchenko@tanu.pro

*** Department of Social and Humanitarian Sciences, Dnipropetrovsk State University of Internal Affairs, Ukraine. ORCID ID: https://orcid.org/oooo-ooo2-1939-7912. Email: itsar@nuos.pro 


\section{2 \\ Petro V. Makushev, Olha V. Minchenko y Iryna V. Tsareva \\ Legal linguistics as a promising field of knowledge \\ La lingüística jurídica como campo de conocimiento prometedor}

\section{Resumen}

La relevancia del artículo está estipulada por la necesidad de estudiar un nuevo y prometedor campo de conocimiento: la lingüística jurídica. El propósito del artículo es estudiar la lingüística jurídica como un campo de conocimiento prometedor. El logro del objetivo del estudio requirió procesar la literatura científica sobre técnicas legales, hermenéutica, interpretación lingüística, oratoria y lingüística legal. El método principal en el estudio de estos temas es el método hermenéutico, que está programado para un nuevo enfoque de comprender e interpretar el lenguaje del derecho y el lenguaje de las leyes, la formación del lenguaje jurídico lo permite comprender el texto como un proceso de interpretación. Se revelan los problemas del campo lingüístico, la interacción de la lingüística y el derecho, se analiza el funcionamiento específico del lenguaje en el campo del derecho. Se estudian las perspectivas de combinar competencia jurídica y lingüística, interpretación de textos de leyes, discursos de jueces y abogados y traducción jurídica. Se concluye enfatizando en la necesidad de destacar un campo de conocimiento como la lingüística jurídica y se esbozan las perspectivas para su desarrollo.

Palabras clave: lenguaje del derecho; técnica jurídica; ámbito jurídico; jurisprudencia; lingüística jurídica.

\section{Introduction}

Law, being a social phenomenon, is undergoing constant change. For example, new generations of human rights are being emerged (Ivanii et al., 2020a). The development of the legal system of Ukraine is conditioned by the rejection of the normative understanding of law, which has long been characteristic of domestic legal science and practice, and this significantly affects the contents of law itself (Kuchuk et al., 2019). At the same time, the processes of international integration, unification and harmonization of legal regulation require improvement of forms of expression of law, in particular, solving linguistic and technical issues in the field of legal regulation, developing a system of science-based requirements, technical and legal rules, techniques and methods.

The well-known German theorist of law rightly states: "The quality of law directly depends on the quality of the language in which it is expressed and through which it is communicated to the addressee" (Shablii, 2012: 52). Unfortunately, not enough attention is paid to the connection between linguistics and jurisprudence. But this aspect objectively exists and is a crucial subject of linguistics: 
Since language is a social phenomenon, there is a tendency to compare it with some aspects of public life. Thus, the institutional nature of language, in which the phenomenon of norm is of great importance, prompted linguists to compare language with legal regulations (Aleksieiev, 1982: 35).

Recently, an increasing number of scientists are beginning to study the outlined phenomenon, namely: Pradid (2001) (legal linguistics), Baltaji (2008) (legal language of law enforcement acts), Liubchenko (2012) (legal terminology). However, there is a need to emphasize once again the issues solved by legal linguistics, to outline the basic directions of linguistics and law field to substantiate the necessity to separate legal linguistics into an independent promising science.

Legal language has traditionally been considered within the framework of an instrumental concept, as a result of which researches possessed purely applied nature. There was a lack of system within relations between lawyers and linguists, which did not contribute to the scientific solution of language issues in theoretical and practical jurisprudence. Lawyers have long ignored the "language issue", and the issue of legal language belonged to the competence of linguists. Therefore, the researches, carried out in recent years, have been mostly in the field of philology. Quantitative and qualitative parameters of legal practice development have led to significant changes in the attitude towards legal language. The analysis of legal texts opens the possibilities of studying the language of law not only as a legal or linguistic concept, but also as a reflection of the linguistic consciousness of the participants of communication within the legal field (Baltaji, 2008).

Legal linguistics is now actively being developed, but recently most studies of the language of law have gradually changed the emphasis, namely not only formal studies of a special language in terms of its terminological composition are on the first place, but they are replaced by interdisciplinary studies. The problems that legal linguistics deals with are multifaceted and complex. Legal linguistics requires both legal and linguistic competence at the same time. The state of legal linguistics research as a science is at the stage of active scientific studies of the language of law around the world.

\section{Methods}

The processes of the European and international integration, harmonization of legal regulation require the improvement of forms of expression of law, in particular, the solution of linguistic and technical issues in the field of legal regulation. Legal linguistics is called for solve a variety of problems of the linguistic field, not only the issues of legal technique, which is of great attention in Ukraine, but also other areas such as linguistic examination of legal documents; legal terminology; theoretical and practical researches in the field of legal translation; speeches of practitioners (judges, 
lawyers); interpretation of legal texts. Thus, the authors consider legal linguistics not only as a branch of linguistics or jurisprudence, but as an individual science performing its own tasks, and possessing an arsenal of concepts, methods, and terminology. The methodological basis of the article was the scientific literature on legal techniques, hermeneutics, linguistic interpretation, public speaking, and legal linguistics.

In the research the following methods were used: hermeneutic method, the method of prediction, and a systematic approach. The hermeneutic method programmed for a new approach to understanding and interpreting the language of laws, legal language forming, and allowed to understand the text as a process of interpretation. It revealed the concept of legal linguistics not only through the interpretation of legal texts but also the semantic bases of legal discourse, which is the system of legal knowledge expressed in language, the language of the law. The method of predicting provided an opportunity to outline the trends of legal linguistics in the future and allowed to determine the prospects for the development of legal linguistics on the basis of existing scientific researches.

A systematic approach allowed a fuller, deeper understanding of the role of language in the legal field, its internal structure with law. Also, using this method was forming an idea of the necessary structuring of legal information, to consider the nature of relationships and interactions between the constituent elements of law and language, the integrity of the system, environmental factors that affect the formation of the language of the law. A systematic approach allowed to justify the essentiality of distinguishing legal linguistics as an individual field of knowledge.

\section{Results and Discussion}

Active integration processes, harmonization of legal regulation in the world in general, and in Ukraine in particular, have led to the urgency of linguistic and technical issues in the field of lawmaking, law enforcement, legal acts interpretation and systematization, which leads to the formation of new scientific directions. The language of law, jurisprudence and practice is one of the indicators of the development level of society legal system. Law can be an effective regulator of social relations only when its internal and external forms meet not only the highest standards of legal technique. The implementation of the principles of law and human rights is impossible without the certainty, clarity and unambiguity of legal provisions, which enshrines the rules of law. The language of regulations and other legal acts, legal science and practice is one of the indicators of the development level of the society legal system. The state should be interested in legal language, understandable to all its citizens, which will be a reliable means of communication in the process of legal regulation, management, and 
legal proceedings. Because the imperfection of legal language negatively affects the formation of legal consciousness, contributes to legal nihilism manifestations (Liubchenko, 2012).

There are two opposing views as to the language of law: some researchers believe that the language of law cannot be defined as a special one, because it is close to the common language in the field of vocabulary. But the other distinguish the language of law as a professional language that is as an alternate of common language to define special subjects, concepts, serving for communication within one professional group. In Ukrainian science, a new nature of legal terminology study was formed in connection with the formation of legal linguistics as one of the relevant areas of study of the general principles of the language of law functioning in the modern world. To form and define any scientific field, it is important to determine the subject of its study. Pradid (2001) emphasizes that the subject of legal linguistics is to study the role and functions of language and speech in the jurisdictional process both historically and at the present stage.

Language used in the fields of law and law enforcement, legal proceedings and notary, legal documentation, legal science and education, legal information and legal journalism is the subject of study of legal linguistics. It defines the functions and specifics of the language of law, its main varieties and genres, the system of rules for making and interpretation of legal texts. Special attention is paid to language issues of law-making and law enforcement. In this connection the following applied directions of scientific and linguistic analysis of legal categories as legislative stylistics, legislative technique, textology, legal terminology, syntax of legislative text, legal hermeneutics, linguistic examination of bills, expert examination assessment of conflict texts, in particular in documentary and information disputes are being developed (Piholkin, 1990).

M.I. Liubchenko (2012) notes that one of the important aspects of the language of law which lacks studies is legal terminology, the accuracy, clarity and intelligibility of which conditions the state of the language of law in general. However, to reduce legal linguistics to the interpretation of texts of normative and legal acts is incorrect. One of the issues of legal linguistics is the question of interpretation of the texts of laws. A special place among a number of legal linguistics' directions development is occupied by the issues related to the study of the quality of court speeches, such as the speeches of the prosecutors, judges, and lawyers.

The language of law is characterized by a set of certain linguistic and stylistic parameters, which also serve as requirements for modern legal text at the same time. They are: formality, clarity, accuracy, unambiguity, completeness, logical sequence, argumentation, exactness of structure, directive nature of legal requirements, codification, generalization, sever normativeness at all language levels, a high degree of standardization, 


\section{6 \\ Petro V. Makushev, Olha V. Minchenko y Iryna V. Tsareva \\ Legal linguistics as a promising field of knowledge}

stylistic homogeneity, neutrality, stability of means of expression, lack of individual authorial features. Western European scholars also structure legal language according to the relevant functional branches (structures) of law:

- W. Otto (1981) - the language of laws (legislative, abstract legal norms assigned by the legislator for both professionals and no lawyers); language of legal science and examinations (comments and discussions of special issues by specialists for specialists); the language of departmental written communication (forms, memos, agendas, etc.); administrative jargon (informal discussion of special issues by specialists).

- L. Eriksen (2002) - legislation, administration, legal proceeding.

- P. Sandrini (1999) - lawmaking (contracts, statutes), administration of justice (court decisions, testimonies, examinations, lawsuits), administrative texts (departmental language and the language of departmental correspondence).

The hermeneutic aspects of law and language, in particular the style of legal documents, their reading and interpretation by non-specialists in the field of law is subject of research by the American and English lawyers and linguists (Diomidova, 2014). Legal technique allows ensuring the systemic, structural, and meaningful literacy and unity of both acts of lawmaking and interpretation of law norms, and acts of law enforcement, aimed at individualizing the regulatory impact of legal norms on a particular life situation and specific subjects.

In our opinion, legal techniques, its scientific development, and implementation into practice ensure the uniformity, quality, and interaction of legal documents, which together constitute a system of legislation, a system of acts of law enforcement, a system of acts of interpretation of law norms. However, legal technique should not be equated with legal linguistics. Although the effectiveness of the legal impact on the life of society depends not only on the semantic literacy of the norm, but also on the "quality" of its design in the form of a legal act.

It should be noted that the institute of legal technique in scientific sources is usually considered in the context of lawmaking as one of its elements or tools used by relevant subjects. It (legal technique) is a system of rules, methods, tools and techniques for preparing the most advanced in form and structure of draft regulations, which provide the fullest and most accurate compliance with the form of regulations of their content, as well as the availability and simplicity of regulatory material. These include requirements for the form of the act, change or cancellation of the adopted act, registration of a new version of the document, as well as formal details, the specifics of the language of legal regulations, definition of terms and special means of ensuring the rules. 
Making a logical and stable system of legal acts, which would correspond in its contents to the trends of social development, is one of the most important legal prerequisites for the implementation of public policy into public and state life. In our opinion, issues of legal and technical execution of legal acts, including acts of law enforcement, arise from the moment of appearance of the acts, which requires their adequate documentation in order to achieve the maximum social effect, which was determined by the author of the document. The relationship between law and language is complex, as both of these categories have an ideal and material embodiment: language is embodied through speech, and law - through a law. Language as a product of human mental activities, a way of forming an opinion, shows the existing connection between language and law, and reveals the essence of the influence of the language factor on the processes of lawmaking and laws making.

According to Maksymova and Matsiupa (2015), it is language, as a means of legislative technique and law enforcement activities, that ensures functioning of the state and its institutions. Thus, the synthesis of linguistics and jurisprudence is necessary to solve a number of issues that require both linguistic and legal knowledge, as language is the only and main material for the design of legal categories. The issue of translation is no less important. We can speak on the example of the translation of the decisions of the European Court of Human Rights (ECHR) and, if necessary, the involvement of an interpreter and the scope of the translation. We would like to pay special attention to the practice of the European Court of Human Rights, because in accordance with Art. 17 of the Law of Ukraine "Enforcement of Judgments and the Application of the Case-Law of the European Court of Human Rights" (2006) courts apply the Convention for the Protection of Human Rights and Fundamental Freedoms (1950) and the practice of the European Court of Human Rights as a source of law.

However, the ECHR's findings in the judgment of the European Court of Human Rights of 28 November in Case of Luedicke, Belkacem and Koc v. Germany (1980), which states that the right to an interpreter/translator concerns, both oral speeches and documentary materials of criminal proceedings. As to the scope of the translation of the written documents, Case of Kamasinski v. Austria (1989) made clear: "Article 6, paragraph 3(e) of the Convention cannot be considered to require a written translation of all written evidence or official documents, subjoined to the proceedings. The assistance of an interpreter should be such as to ensure that the defendant understands the case against him and his defense, in particular through the fact that with the help of the interpreter he (defendant) can put forward his version of events".

However, there are questions to solve with the official translation of ECHR's judgments in cases where Ukraine was not a party, since a number 
of ECHR's judgments do not currently have an official translation into the state language. The courts should use the official translation of the Court's decision, which is published in an official publication or, in the absence of a translation, the original text. But working with the original text of the decision of the ECHR is quite challenging without proper philological training, and no one will check the correctness of the translation by the judge and, accordingly, the application of such a decision of the ECHR.

National courts mainly appeal to the prescription of a legal act, which they use as an argument for their own decision, without resorting to the interpretation of this prescription. The European Court of Human Rights, applying the provisions of hermeneutics, takes a different view of the text of the Convention for the Protection of Human Rights and Fundamental Freedoms, considering it possessing implicit nature. And this raises the issue of the adequacy of understanding of each other by lawyers - representatives of various legal traditions. Thus, legal linguistics is designed to solve a variety of issues of the linguistic field, namely: linguistic examination of legal documents; making recommendations for the development of texts of laws and other regulations; legal terminology (unification and harmonization); theoretical and practical research in the field of legal translation; speeches of practitioners (judges, lawyers); interpretation of legal texts; legal technique.

\section{Conclusions}

Language is an integral part of the legal system with certain traditions, functions, features and properties. Language is the national basis for reforming the legal system, so the separation of the language of law into an independent science, based on the synthesis of linguistics and jurisprudence, will have a positive impact not only on the language of law but also on legal practice in general. Legal linguistics is necessary to improve the efficiency of the language of law and the quality of legal documents by developing linguistic and stylistic principles and rules of lawmaking, finding the optimal use of language tools in various areas of legal communication. Legal linguistics should be considered not only as a branch of linguistics or jurisprudence, or an interdisciplinary phenomenon, but as a separate independent and promising science.

The urgency of further research is stipulated for the necessity to generalize the work of Ukrainian and foreign scholars on the formation and development of legal linguistics, the study of problems of linguistic and law field - those that are at the intersection of law and linguistics; substantiation of the status of legal linguistics as a separate science; selection, specification and detailing of the main directions of scientific research; effective use of linguistic knowledge in law-making, law enforcement and judicial practice. 


\section{Bibliographic References}

ALEKSIEIEV, Serhii. 1982. General theory of law. Legal Literature. Moscow, Russian Federation.

BALTAJI, Polina. 2008. Legal language of law enforcement acts. National Academy of Sciences of Ukraine Institute of State and Law. Kyiv, Ukraine.

CASE OF KAMASINSKI V.AUSTRIA. 1989. Application No. 9783/82. Available online. In: http://hudoc.echr.coe.int/eng?i=001-57614. Consultation date: $08 / 04 / 2020$.

CASE OF LUEDICKE, BELKACEM AND KOCV. GERMANY. 1980. Application No. 6210/73; 6877/75; 7132/75. Available online. In: http://hudoc.echr. coe.int/eng?i=001-57529/. Consultation date: 28/04/2020.

CONVENTION FOR THE PROTECTION OF HUMAN RIGHTS AND FUNDAMENTAL FREEDOMS. 1950. Available online. In: https:// rm.coe.int/1680063765. Consultation date: 19/04/2020.

DIOMIDOVA, Olena. 2014. "Modern legal linguistics: Prospects for development" In: Language and Society. Vol. 5, pp. 18-22.

ERIKSEN, Lars. 2002. "Introduction to the system of legal terminology". Legal Terminology: Congress Reports of the 12th European Symposium on Language for Special Purposes, Brixen/Bressanone 1999. Edited by L. Eriksen and K. Luttermann. LIT Verlag. Münster, Germany.

IVANII, Olena; ORLOVA, Olena; KUCHUK, Andrii. 2020a. "Biotechnology as factor for the fourth generation of human rights formation" In: Journal of History Culture and Art Research. Vol. 9, No. 1, pp. 115-121.

IVANII, Olena; ORLOVA, Olena; KUCHUK, Andrii. 2020b. "Business and human rights: Dialectics of interaction" In: Advances in Economics, Business and Management Research. Vol. 129, pp. 56-62.

KUCHUK, Andrii; SERDIUK, Liliia; ZAVHORODNIA, Yuliia. 2019. "Modern law education in the context of natural understanding of law" In: The Asian International Journal of Life Sciences. Vol. 21, No. 2, pp. 359-370.

LAW OF UKRAINE. 2006. Enforcement of judgments and the application of the case-law of the European Court of Human Rights. Available online. In: http://sutyajnik.ru/rus/echr/etc/2006_law_ukraine.htm. Consultation date: $27 / 04 / 2020$.

LIUBCHENKO, Marianna. 2012. Legal terminology: Concepts, features, types. Yaroslav Mudryi National Law University. Kharkiv, Ukraine. 
MAKSYMOVA, Svitlana; MATSIUPA, Kseniia. 2015. "Current issues of legal linguistics” In: Eurasian Union of Scientists. Philological Sciences. Vol. 5, No. 14, pp. 130-133.

OTTO, Walter. 1981. "The paradox of a technical language" Stuttgart, Germany: Klett-Cotta. In: Public Usage. Vol. 2, pp. 44-57.

PIHOLKIN, Albert. 1990. Language of law. Legal Literature. Moscow, Russian Federation.

PODLECH, Adalbert. 1976. "Legal linguistics" Verlag C.H. Beck. In: Law and Related Sciences. Vol. 2. pp. 105-116.

PRADID, Yurii. 2001. "Legal linguistics as a separate branch of knowledge" In: Bulletin of the Luhansk Institute of Internal Affairs. Vol. 3, pp. 246-249.

PRADID, Yurii. 2002. "Legal linguistics and some current issues of legislative practice" In: Bulletin of the Luhansk Institute of Internal Affairs. Vol. 1, pp. 120-126.

SANDRINI, Peter. 1999. Translation of legal texts. Narr. Tübingen, Germany.

SHABLII, Olena. 2012. German and Ukrainian legal translation: Methods, problems, prospects. Publisher PE Lysenko M.M. Nizhyn, Ukraine. 

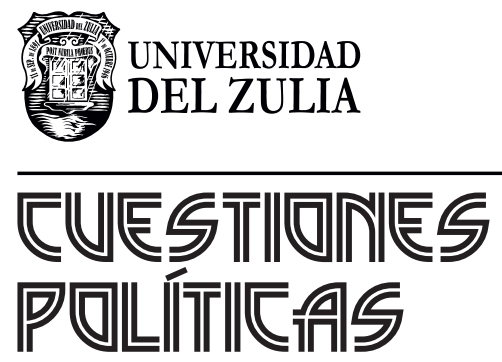

Vol.39 No 68

Esta revista fue editada en formato digital y publicada en enero de 2021, por el Fondo Editorial Serbiluz, Universidad del Zulia. Maracaibo-Venezuela 